\title{
Re-reading Embodied Texts - an Interpretation of Rune-stones
}

\author{
Anders Andrén
}

\begin{abstract}
Rune-stones have been a major field of research in philology, archaeology, art history and history during the $20^{\text {th }}$ century. Most of these studies have been based on the thorough editions of rune-stones published in Scandinavia during the century. The aim of this article is to question some of the fundamental principles of these editions, and to initiate a new type of interpretation based on the complex interplay between images and texts on the rune-stones. Elements of a more visual understanding of the monuments are presented, as well as some examples of a new contextual reading, which sometimes alter the philological interpretations in the rune-stone publications.
\end{abstract}

Anders Andrén, Institute of Archaeology, University of Lund, Sandgatan 1, SE-223 50 Lund, Sweden.

\section{THE STUDY OF RUNE-STONES - A BRIEF SURVEY}

Rune-stones have been studied during 400 years in Sweden. In fact, the very start of Swedish antiquarian tradition in the late $16^{\text {th }}$ and early $17^{\text {th }}$ centuries was directly related to the recording of rune-stones in the realm. Inspired by epigraphic research on classical inscriptions, Johannes Bureus (1568-1652), later the first state antiquarian, began the systematic recording of rune-stones in 1599. The work of Bureus and his assistants was followed up by generations of antiquarians in the $17^{\text {th }}$ and $18^{\text {th }}$ centuries, most notably by Johan Hadorph (1630-1697). He planned a large edition of all Swedish rune-stones, but his work was published posthumously only in 1750, when no less than 1173 runestones appeared in an edition called Bautil (Schück 1935-44; Svärdström 1936; KlindtJensen 1975).

In the $17^{\text {th }}, 18^{\text {th }}$ and first half of the $19^{\text {th }}$ centuries, studies of rune-stones were part of a broad antiquarian tradition. As part of a glorious past, rune-stones were registered together with churches, hill forts, graves, ancient objects, old books, medieval documents and legends. In the second half of the $19^{\text {th }}$ century, however, the new idea of a vast prehistory without any written records, and the general trend of empirical specialisation, led to a successive division between archaeology and rune-stone studies. The ordering of objects and monuments became the task of archaeologists, whereas rune-stones were recorded, interpreted and published by successively more specialised philologists.

In the early 1880s, the Royal Academy of Letters, History and Antiquities decided to start a new edition of all Swedish runestones, "which could meet the demands of modern science" (Öl p.10, cf. Hildebrand 1884). After fieldwork and archival studies, the first volume of Sveriges runinskrifter (Runic inscriptions of Sweden) was published in the year 1900 (fig. 1). Today most of the 


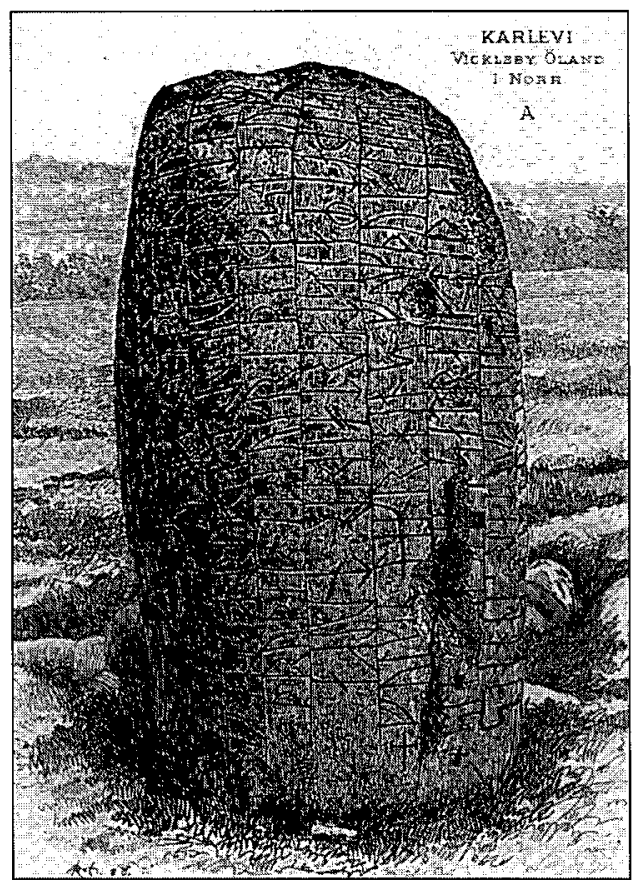

Fig. 1. Rune-stone at Karlevi on Öland (Öl 1). This monument was the very first rune-stone presented in Sveriges Runinskrifter in the year 1900. It represents an early type of mine-stone from about the year 1000, with a linear text but containing a highly elaborate poetic language. According to Sven B. F. Jansson's translation (Jansson 1962:125) the inscription runs:

"This stone was erected after Sibbe the good, Foldar's son, but his host placed on the island... Hidden lies the man whom the greatest virtues accompanied - most men knew that - 'executor' of the goddess of battles [i.e. the warrior, lord] in this mound. A more honest battle-strong god of the wagon of the mighty ground of the sea-king [i.e. a more honest battle-strong sea-captain] shall not rule over land in Denmark".

Swedish rune-stones have been published in this edition, but the major part of the corpus was completed in 1958, when the final volume covering the province of Uppland appeared. Similar editions have been made of the rune-stones in Denmark and Norway, including the rune-stones in former Danish and Norwegian provinces in present-day Sweden (cf. DR and NIyR). Thanks to these editions nearly the whole corpus of Scandinavian rune-stones have been thoroughly published in the $20^{\text {th }}$ century.

It has been the work of philologists to prepare and edit these publications, since the main aim has been to give a convincing semantic interpretation of the text on every rune-stone. The pervading method has been to publish one or more pictures of the runestone and its inscription, a transliteration of the rune characters into Latin letters, a normalised text in Old Icelandic, and a translation into a modern language. Although the philological interpretation has been the focus of the publications, the editors of Sveriges runinskrifter have always given an account of the location of rune-stones, and the ornaments and images on the monuments. Especially Elias Wessén (1889-1981), who was editing volumes from 1932 to 1962, developed the sections on location and ornaments. In Denmark, similar perspectives were developed by Erik Moltke (1901-1984) in Danmarks runeindskrifter as well as in a later general survey of runic inscriptions in Denmark (Moltke 1976).

Owing to the thoroughness of the editions, Sveriges runinskrifter and its counterparts in Denmark and Norway have been the natural starting-point for all studies of rune-stones in philology, archaeology, art history, history, and church history in the $20^{\text {th }}$ century (Owe 1995). In the last few decades especially, the study of rune-stones has expanded considerably, covering a whole range of different topics. In philology issues such as orthography (Lagman 1990; Williams 1990), words (Peterson 1994), poetry (Hübler 1996), the function of runes (Bæksted 1952; Moltke 1976:17 ff.), rune-carvers (Thompson 1975; Philippa 1977; Arend 1978; Crocker 1982; Axelsson 1993; Åhlén 1997; Stille 1999; cf. Brate 1925), and personal names and placenames (Salberger 1978) have been investigated. The chronological and regional pattern of stone-raising has also been an important philological issue (Palm 1992; cf. von 
Friesen 1913, 1928, 1933). In archaeology the classical topics have been chronology and regional variation in the ornamental styles on the rune-stones (Holmqvist 1951; Wideen 1955; Christiansson 1959; Gräslund 1991, 1992, 1994; Lindblad \& Wirtén 1992; Sundqvist 1996) as well as the spatial location of the rune-stones (Ambrosiani 1964; Hyenstrand 1974; Wijkander 1983; Larsson 1990, 1997; Wilson 1994; Johansen 1997; Zachrisson 1998). In art history stylistic analysis and iconographic studies have dominated (Bergman 1948; Fuglesang 1980, 1981 and 1986), whereas historical investigations have focused on political history (Lönnroth 1982; Lindkvist 1988; Sawyer 1991) and heritage and property (Carlquist 1977; Sawyer 1988, 1989; Sandahl 1996). In church history above all aspects of Christianisation have attracted attention (Ljungberg 1938; Hallencreutz 1982a, 1982b; Segelberg 1983).

However, the complex character of the rune-stones, as monuments in a landscape, as works of art and as written documents, means that many rune-stone studies transgress the traditional disciplinary lines. Philologists have studied design (Thompson 1975), petrography (Hagenfeldt \& Palm 1996) as well as paganism (Grønvik 1981, 1985), Christianisation (Moltke 1976:180 ff,; Sjöberg 1985; Williams 1993, 1996a, 1996b) and social structure (Moltke 1976:147 ff., 233 ff.; Strid 1987). Archaeologists and historians alike have drawn attention to the role of women (Kyhlberg 1983; Saywer 1988; Jesch 1991a:42 ff.; Saywer \& Saywer 1993; Gräslund 1989,1996$)$. And many archaeologists have investigated rune-carvers (Berg 1987; Källström 1992), Christianisation (Gräslund 1985, 1988, 1991; Elgh 1987; Söderqvist 1993; Andersson 1995; Ekblad 1997; Moström 1998), property rights (Lindström 1992; Zachrisson 1994), iconography (Christiansson 1953, 1995; Thráinsson 1994; Lager 1995; Zachrisson 1998), social structure (Ragnesten 1978; Randsborg 1980; Christophersen 1982; Claesson 1982; Carlsson 1985;
Andersson 1992; Bjurström 1996), military organisation (Varenius 1998), mental landscapes (Johansen 1997), and even formulas and words (Herschend 1994; Johansson 1996; Norr 1998). In some cases studies have been made in disciplinary cooperation (Gustavson \& Selinge 1988)

As a summary of rune-stone studies in the $20^{\text {th }}$ century I would like to point out the following characteristics. The interpretation of the rune-stones and their texts has been based on philological interpretations of the texts, on interpretation of images, on surveys in time and space of different aspects of the texts, and on additional aspects of the runestones, such as their location and spatial relation to other ancient monuments. Owing to the complexity of the rune-stones, many studies have been based on comparisons of different aspects of the monuments, such as texts and ornaments or texts and locations. Although these comparisons have led to new and interesting results in many cases, it is characteristic that the semantic interpretations in the rune-stone editions have usually been taken for granted.

In this article I want to start a new discussion of the interpretation of rune-stones by questioning the fundamental principles of the edition of the Scandinavian rune-stones. The published corpus of nearly all the Scandinavian rune-stones is indispensable, but the general method of philological interpretation, from image, via transliteration and normalisation to translation, reduces the runic inscriptions to linear texts - which they seldom are. This reduction has been further underlined by perspectives that the animal bodies on which many texts were cut had no special meaning but were only decorative basis for the text. I maintain that the reduction from runic inscription to linear text and the reduction from animal art to decoration have reduced the meaning of the inscription and ultimately of the rune-stone as a whole. Therefore I would argue for a new kind of re-reading, based primarily on combining in- 
scriptions, ornaments and images in joint interpretations. Location should be added as a further aspect of the interpretation, although I will not consider the place of monument in this article.

I see this re-reading as an example of historical archaeology, and especially of what I recently labelled as "integrated discursive context" and as "association" (Andrén 1998:149 ff., 168 ff.). By these concepts I understand a contextual reading based on the often complex interplay between image and text. In the case of rune-stones this interplay implies that the images were not only illustrations, but also extensions, complements, reinforcements or variations of the messages conveyed by the texts. Therefore, an important aspect of a contextual reading will be to develop a kind of "visual literacy" (cf. Berlo 1983), which may enable us to understand how the interplay of image and text actually worked on the rune-stones.

\section{"LET THE ONE SOLVE WHO CAN"}

A good starting-point for a renewed discussion of the interpretation of rune-stones is the rune-stone at Nybble on the island of Selaö in northern Södermanland. The inscription on this monument ends with the sentence "let the one solve who can" (Sö 213, fig. 2); an expression which is repeated on several other stones in central Sweden. At Nybble the final sentence can be explained by a partly abstruse runic inscription, but in other cases these expressions are inserted into texts that are not themselves particularly difficult to interpret. Therefore, these formulas can be understood as more or less concealed requests to make some kind of broader interpretation of the stones. The most provocative request comes from the long inscription at Hillersjö in southern Uppland (U 29, cf. fig. 3), which starts with the word raPu ("read/solve/interpret") cut into the eye of a snake. Here it is quite clear that the runecarver, named Torbjörn Skald, requests the reader and viewer to use the eye as the active sense. To me, this means that we should not just read the inscription as a linear text, but interpret it in its totality. Consequently, we should take into consideration that the text is written on the body of two snakes, and that the text is intertwined in itself, by the plaiting of the two bodies and their legs and tails.

The problem for a modern viewer to make such a combined interpretation is that the different elements of the rune-stones for such a long time have been studied by different disciplines. The texts have been studied and interpreted by philologists, whereas archaeologists and art historians have studied the ornaments and images. Animal art has been reduced to decoration without further meaning, just as the inscriptions have been reduced to linear text.

Ever since the beginning of modern archaeology in the $19^{\text {th }}$ century, attention has been paid to animal art (cf. Karlsson 1983).

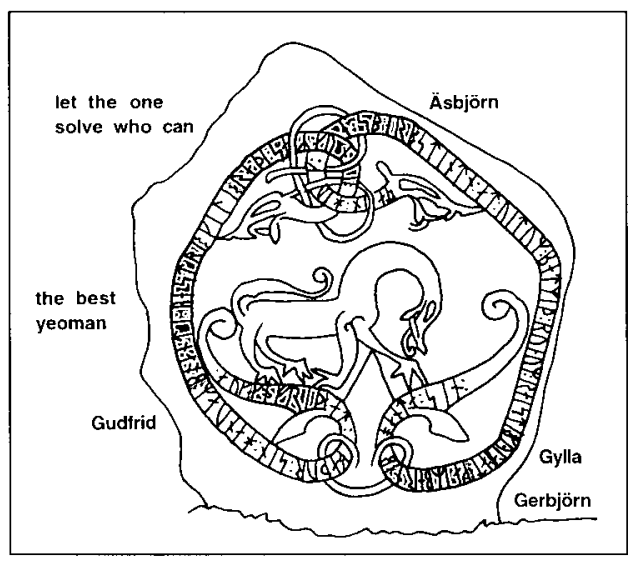

Fig. 2 Rune-stone at Nybble on the island of Selaö in northern Södermanland (Sö 213). The runestone represents a transitional type of monument, with two twisted snakes as well as a text written in verse. According to a translation based on Sven B. F. Jansson (Jansson 1962:150) the inscription runs:

Right snake: "Äsbjörn hewed the stone / coloured as a memorial / he bound it with runes / Gylla raised it / after Gerbjörn her husband".

Left snake: "and Gudfrid after his father / He was the best yeoman in Kil / Let the one solve who can". 
Among the important contributions are Müller 1880; Salin 1890, 1904; Shetelig 1909, 1949; Brøndsted 1920, 1924; Åberg 1921, 1941; Lindqvist 1931; Holmqvist 1951, 1955; Christiansson 1959, Ørsnes 1966, 1969; Fuglesang 1978; Haseloff 1981. The prevailing perspective in these studies has been to regard animal art as decoration without any deeper meaning. Therefore, the main aim of the investigations has been to define different styles in time and space, and to follow different stylistic influences on animal art. A recent survey of animal art from this perspective is Wilson 1995.

Another minor line of thought has, however, existed during the whole century, and has in the last decade played an important role in the debate on animal art. Already in the early 1890 s the Swedish archaeologist Sven Söderberg argued that animal art should be regarded as a parallel expression to skaldic poetry (Söderberg 1905-however, the article was written in 1892-3). To him animal art was thus not a neutral decoration, but could instead be viewed as an analogy to the difficult and complex art of poetry, practiced by well-known specialists called skalds. Similar ideas have later been expressed by the Norwegian literary historian Hallvard Lie (Lie 1952, 1963) the Norwegian theologist Anders Bugge (Bugge 1953) and the Russian historian Aaron Gurevich (Gurevich 1985). Inspired by recent archaeological debate on meaning of material culture, some archaeologists in the 1990s have underlined an inherent meaning of animal art, with associations above all to pagan cosmology (Thráinsson 1994; Kristoffersen 1995; Hedeager 1997, 1999). Others have turned back to the ideas of Söderberg and Lie, underlining the analogous construction of animal art and skaldic poetry as complex and partly concealed expressions (Johansen 1997; Zachrisson 1998; cf. Andrén 1989, 1993).

In spite of these new perspectives on animal art, the interpretation of the runestones has not changed fundamentally. Some of the images on the rune-stones have been reinterpreted, but without references to the texts, and the texts from the general editions are still used as face value. Apart from an interesting combined interpretation of texts and images on the large rune-stone at Jelling (Fuglesang 1986), there is only a single hint that the animals on the rune-stones may be connected with the content of the texts (Sawyer 1988:15 ff.). No one, however, has tried to make a more general re-reading of the rune-stones, based on an associated close reading of texts, ornaments and images. In the following lines I will initiate such a rereading, with seminal inspiration from recent studies on art and epigraphic writing in Mesoamerica (Berlo 1983; Hanks \& Rice 1989; Marcus 1992), Egypt (Baines 1989) and the classical world (Zanker 1988; Bérard et al. 1989; Svenbro 1993), as well as from interart studies (Lagerroth et al. 1993).

\section{ELEMENTS OF UNDERSTANDING}

Although my aim is to interpret the runestones in a new kind of linguistic and visual totality, it is necessary to examine different elements per se in this totality. Unfortunately one important element for the interpretation of rune-stones is generally lacking today, namely colour. From occasional finds we know that the rune-stones were painted, and sometimes repainted, in bright colours. A well-preserved example is a runic gravestone from the church of St Lawrence in Linköping, which was painted in five colours (Jansson 1962:152-3). Two snakes were coloured red and two snakes were painted black, whereas the background was held up by bluish grey and the knots binding the snakes together by light bluish grey. Finally, the runes were painted alternatively white and black, emphasising some of the words. Although this element is generally lacking, it is possible to define other important elements of understanding, by looking at the changes of the texts and the layout of the rune-stones through time. 


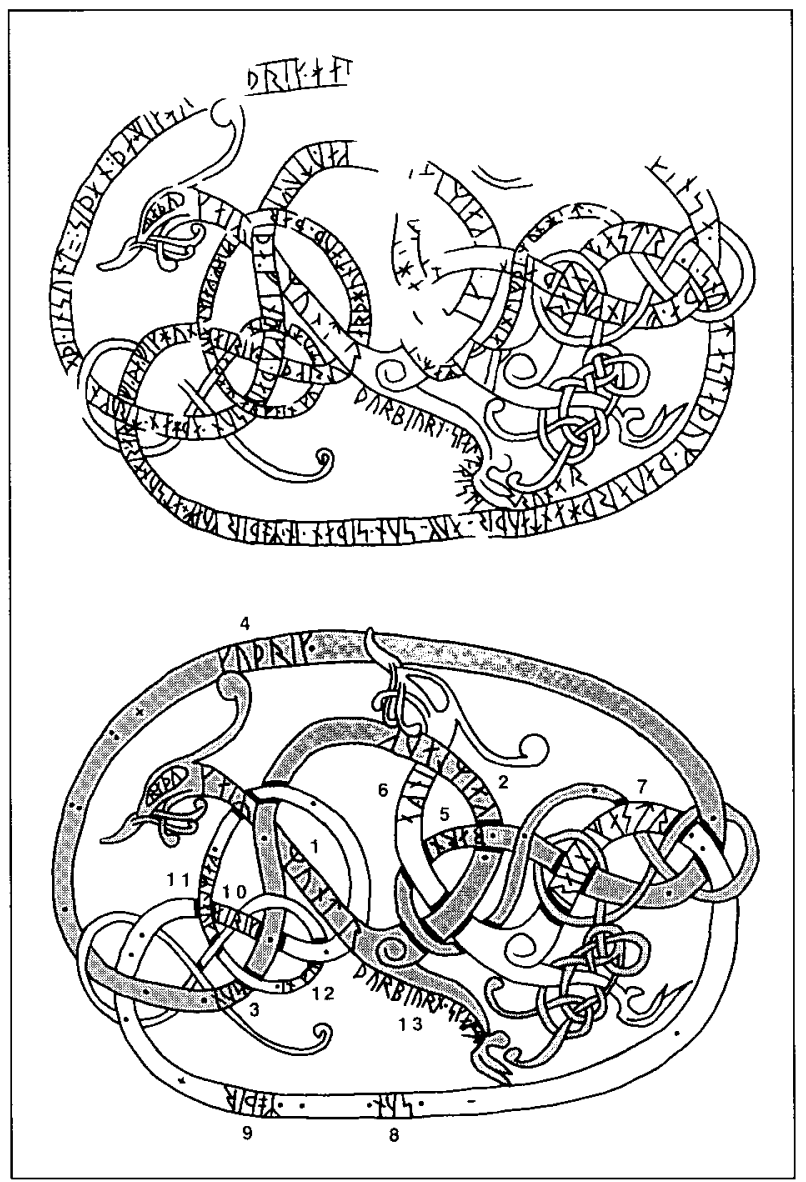

Fig. 3. Rune-carving at Hillersjö in southern Uppland $(U$ 29). The figure shows the carving as preserved (above) and as reconstructed in its main design (below). The reconstruction is shown with names and key words in the inscription as well as with all divisions of words (points or thick lines). According to a translation based on Sven B. F. Jansson (Jansson 1962:77) and Birgit Saywer (Saywer 1988:17) the inscription runs:

Eye in left snake: "Solve!"

Left snake (shaded): "Germund [1] took Gerlög [2] a maiden as wife. Then they had a son [3] before he [= Germund] was drowned and then the son died. Then she had Gudrik [4] as her husband. He... Then they had children [5], but only one girl survived. She was called"

Right snake: "Inga [6]. Ragnfast [7] of Snottsta took her to wife. Thereafter he died and the son [8]. And the mother [9] [ = Inga] inherited from her son. Then she had Erik [10] as her husband. Then she died. Then Gerlög [11] inherited from Inga [12] her daughter:"

Below left snake: "Torbjörn skald [13] carved the runes".

The early rune-stones, from the earliest examples in the $4^{\text {th }}$ century until the late $10^{\text {th }}$ century, are usually stones with simple lines of runes. The text is linear in a modern sense, but the content is sometimes difficult to understand because the message is more or less concealed. The long inscription at Rök in western Östergötland (Ög 136) from about 800 is partly written in cipher and only possible to read with the help of a code placed on top of the stone. Other stones are written in verse, like the stone at Karlevi on Öland (Öl 1, cf. fig. 1) from the late $10^{\text {th }}$ century, which is loaded with difficult poetic metaphors (heitis and kennings).

Only in the $11^{\text {th }}$ century did the texts and the layout of the rune-stones change into mixed expressions. The texts usually became linguistically more simple as prose, whereas the layout became successively more complex with animals and ornamental loops intertwined in complex patterns. Thus, it is possible to trace a passage from linguistic to visual complexity among the rune-stones from the late $10^{\text {th }}$ century until the early $12^{\text {th }}$ century (cf. figs. 1, 2 and 3, and cf. Thráinsson 1994:46 ff.; Zachrisson 1998:129 ff.). Important elements in this late visual complexity are animals with texts on their bodies, animals without texts but twisted around other animals, directions of the text, wordcrossings and different kind of images which are inserted by the animals with texts.

\section{Snakes with texts}

When runic inscriptions about the year 1000 
began to be combined with animal bodies they were cut into animals that might be classified as snakes or dragons. There was no clear distinction between these creatures, and consequently I call them snakes. Recently Birgitta Johansen has made a study of the important snake motif in late Iron Age Scandinavia, and tentatively interpreted them in general as protective creatures, especially of women and treasures. She has, however, interpreted the snake on the late rune-stones more specifically as protector of the farm or the village, surrounding the inherited property as an equivalent to the Midgard serpent surrounding the world (Johansen 1997:143 ff., 224; also cf. Zachrisson 1994, 1998). By comparing inscriptions of rune-stones containing one snake with those containing two snakes, I maintain that it is possible to define a somewhat different meaning, but with clear connections to Johansen's interpretation. In most cases the snake seems primarily to represent a family, although including other associations to a family, such as inheritance, property, land and settled space.

A good example of this interpretation is the above-mentioned inscription at Hillersjö (fig. 3). It contains two snakes, and the text is clearly divided between them. On the first snake a certain Gerlög, who commissioned the inscription, mentioned herself, her two husbands and their children, and on the second snake she mentioned her daughter Inga and her two husbands and the daughter's only child. Thus, the two snakes visually mark out the families created around two women; one mother and one daughter. We are in the lucky situation that the daughter Inga had another four rune-stones raised in another part of Uppland (U 329-332; cf. Zachrisson 1998:165 ff.). On these stones she commemorated her first husband, their son, her sisters-in-law, her father-in-law, and her husband's steward (huskarl). On three stones she only used one snake to describe the family, but on the one where her father-inlaw is mentioned she used two snakes (fig.
4). Thus, from her perspective the husband, the son, the sisters-in-law and the steward belonged to the same family, whereas the father-in-law belonged to another family. From these cases it is clear that the snakes represented families, but not in a clear-cut sense. What could be regarded as one family or two families differed according to the context, and consequently the interpretation of a rune-stone must always be based on both text and ornament.

An interpretation of snakes as representation of families and their properties is well in accordance with the Gutasaga (Saga of the Gotlanders) from about 1200 . The saga is a mythological introduction to the provincial code of Gotland, and it gives a historical background to the island and its laws. According to the saga, Gotland was initially inhabited by a single couple. The first night when they slept on the island, the wife dreamt that three snakes were twisted in her stomach. Her husband interpreted the dream as a vision of their three sons that would eventually inhabit the island and divide it between them in three parts. The snakes, in other words, represented the future families of the three sons and their respective possessions on the island (Holmbäck \& Wessén 1943:291).

Finally, by interpreting the large snakes on the rune-stones as families and their respective properties, it is important to underline that snakes with texts are nearly always of identical size. This may indicate that the families mentioned had the same hierarchical position, and that paternal and maternal kinship were regarded as equal.

\section{From head to tail}

Since the snakes represented families in some sense, it is essential where the texts were cut into the animal bodies: Where does the text start and where does it end? Most inscriptions start in the snake's head, and recently this fact has been explained as a kind of reading device (Norr 1998:20 ff.). I would rather argue that the direction of the text in itself 


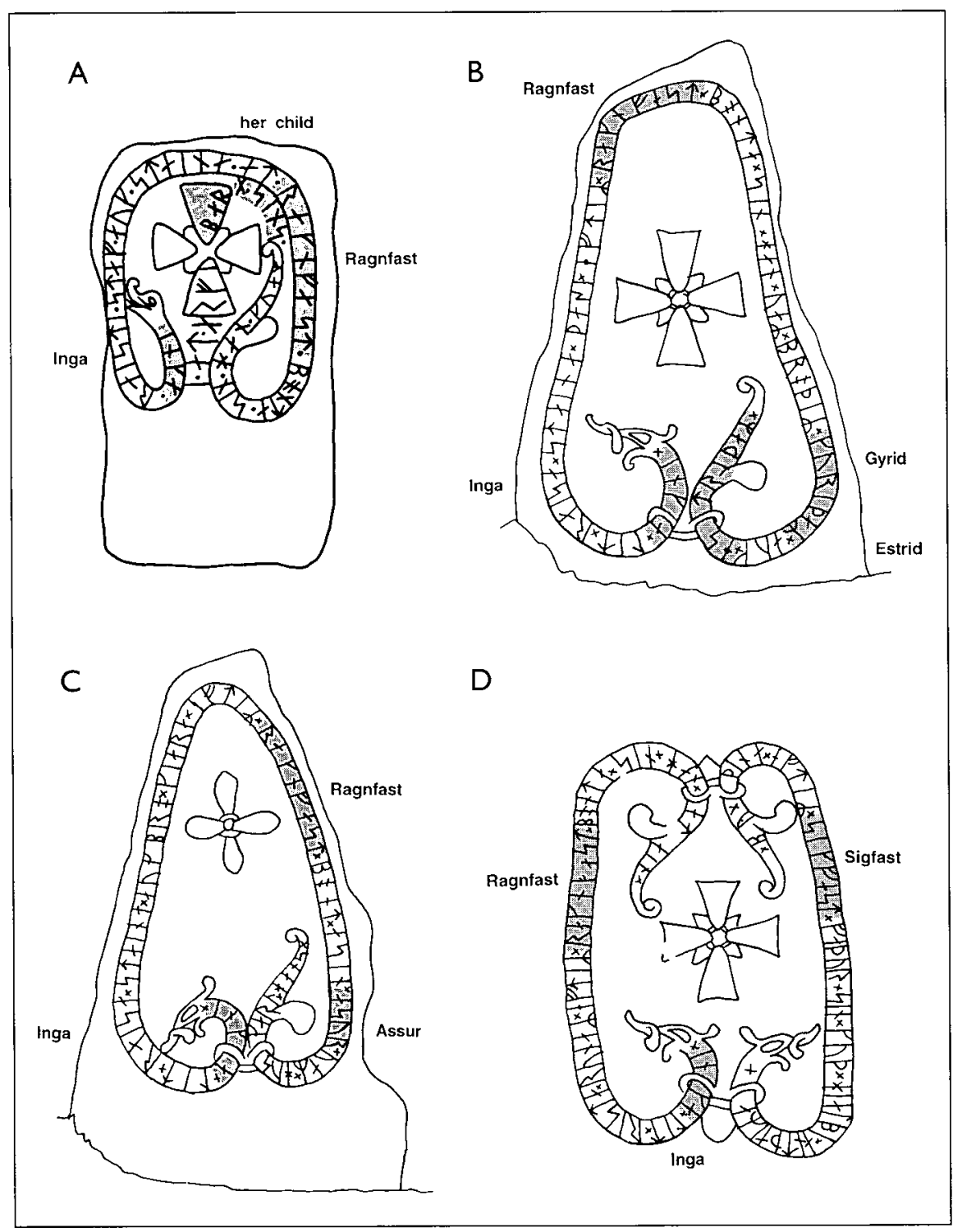

Fig. 4. Four rune-stones raised at Snottsta in southern Uppland, by Inga Gudriksdotter from Hillersjö (cf.fig. 3) after her husband Ragnfast Sigfastsson. The stones show how Inga Gudriksdotter used one snake in three cases and two snakes in one case to represent the family. Two snakes are only used when her father in law is mentioned. The inscriptions run as follows: A (Vreta, U 332): "Inga raised staff and stones after Ragnfast, her husband. She came into inheritance after her child"

$B$ (Snottsta, U 329): "Inga had these stones raised after Ragnfast, her husband. He was brother to Gyrid and Estrid"

$C$ (Snottsta, U330): "Inga had these stones raised and made the bridge after Ragnfast, her husband. Assur was his servant"

$D$ (Snottsta, U 331). Left snake: "Inga had these munes carved after Ragnfast, her husband. He owned alone" Right snake: "this village after Sigfast, his father. God help their souls". 
had a meaning. In most texts the persons that commissioned the stones are mentioned at the beginning and the commemorated dead persons are mentioned at the end (cf. figs. 4, $5 \mathrm{C}, 6 \mathrm{C}$ and $\mathrm{D}, 8,9,10 \mathrm{E}$ and $11 \mathrm{~B}$ ). The first person mentioned, usually placed in the snake's head, may virtually have been the head of the surviving family, and the order of the other persons may have been an indication of the ranking within the family (cf. Saywer 1988:15 ff.). Usually a man is mentioned as the first person in the head, but sometimes a wife or a mother is mentioned before brothers and sons. These cases may indicate a situation where a woman is head of a family, due to her property right, for instance as the single heir of an estate.

Although most texts start at the snake's head, a few inscriptions start at the tail (cf. fig. 6B). This divergence may sometimes be explained by comparing the iconography with the text. An illuminating example is the runestone at Vänga in eastern Södermanland (Sö 3 ). The inscription starts at the tail, mentioning a man and a wife who raised the stone in memory of a dead son. The text ends at the head, however, with a concluding sentence mentioning a brother of the dead man. The reverse direction of the text may in this case be an indication that the parents wanted to point out that the surviving son was more honourable than themselves, possibly through service outside the family.

\section{Snakes without texts}

Apart from large snakes with texts, a large number of late rune-stones also contain many small snakes that are twisted around the large animals. The significance of these small snakes is indicated by the process by which they were created. It is possible to trace a successive transition during the $11^{\text {th }}$ century, from short additions of the main texts to small snakes twisted around the main texts. In the latter cases the small snakes are twisted around passages of the text, which give the same kind of extra information as the earlier textual additions. Consequently, I see the textual additions outside the main text-band as deliberate compositions, and not as "lack of planning" or "faulty planning" of the design of the rune-stones (cf. Meijer 1992).

The pervading pattern is that the textual additions as well as the texts surrounded by small snakes emphasise information about relations outside the family in its narrow sense. Above all, the textual additions and the small snakes underline passages about men that took part in raids abroad or were in service of a lord. The examples in fig. 5 mention outside the main text-bands that the commemorated men had been in Greece or died "in the East". Many small snakes also emphasise the rune-carver, indicating that the rune-carver was in the service of the person who had the stone raised. The examples in fig. 6 again show how rune-carvers signed the rune-stones outside the main loop where the close family is mentioned. Divergence from this pattern may in a few cases support the interpretation of the small snakes. On one of the rune-stones at Gripsholm in northern Södermanland (Sö 178) a rune-carver is mentioned in the main inscription, but without any extra small snakes around the text. In this case, however, the rune-carver was a brother of the dead woman commemorated on the stone, and hence the rune-carver was a member of the immediate family.

Because the small snakes indicate relations outside the close family, the size of the snakes seems to be significant. Contrary to the large similar sized snakes with texts, the very difference of size between large snakes with texts and small snakes without texts signifies hierarchical relations, upwards as well as downwards, for instance to Byzantine emperors, kings, earls and chieftains as well as to rune-carvers in service as craftsmen.

\section{Word crossing}

A less common element in the rune-stones is word crossing, which is the result of snakes with texts that are closely intertwined with 
A

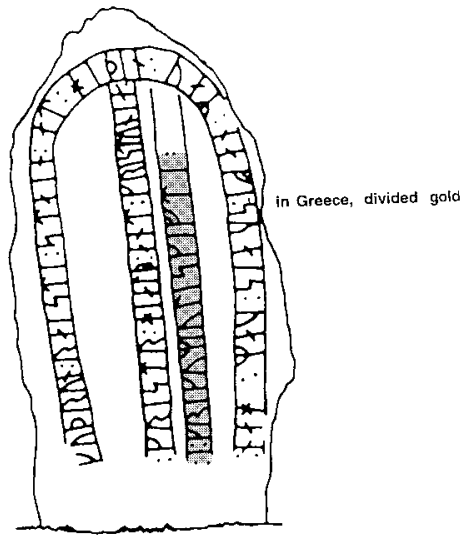

C

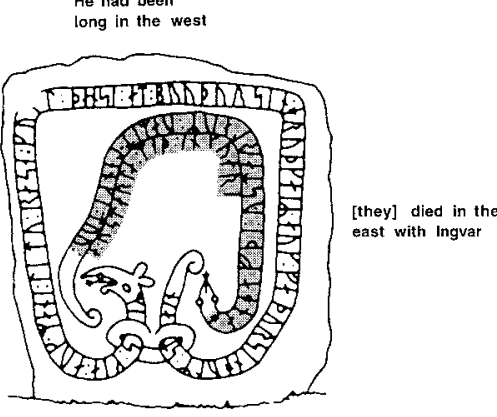

B

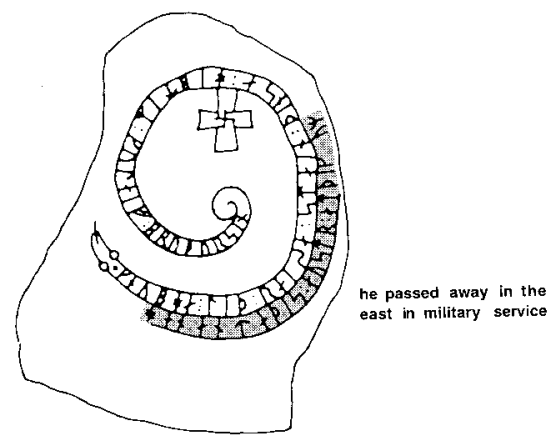

D

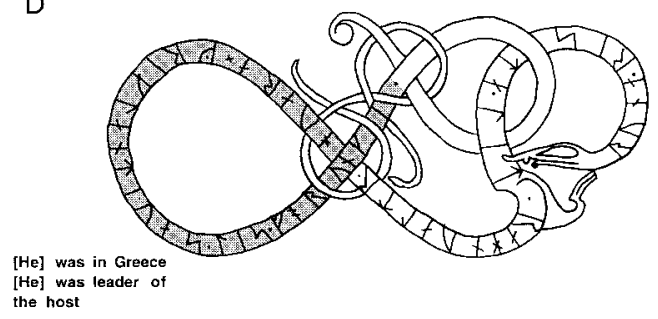

Fig. 5. Four rune-stones which illustrate the transition from textual additions to small snakes without texts. All the examples are related to military service abroad.

A (Grinda, Sö 165). Main text-band: "Gudrun raised the stone after Hedin. The] was nephew to Sven. He was"

Right additional text-band: "in Greece, divided gold"

Left additional text-band: "Christ help all souls of Christians".

$B$ (Fredriksdal, Sö 33). Main snake: "Gnupa had this stone raised after Gudlev, his brother" Textband outside main snake: "He passed away in the east in military service"

C (Tystberga, Sö 173). Main snake: "Muskia and Manne had this memorial raised after their brother Rodger and their father Holmsten"

Minor snake: "He had long been in the west"

Text by the minor snake: "[They] died in the east with Ingvar"

$D(E d, U$ 112). The inscriptions are cut on two sides of a large block of stone.

Main snake (not shown in the figure): "Ragnvald had the runes cut in memory of Fastvi, his mother, Onäm's daughter. She died in Ed. God help her soul.

Minor snake (shown in the figure): Ragnvald let the runes be cut. [He] was in Greece, [he] was leader of the host". 


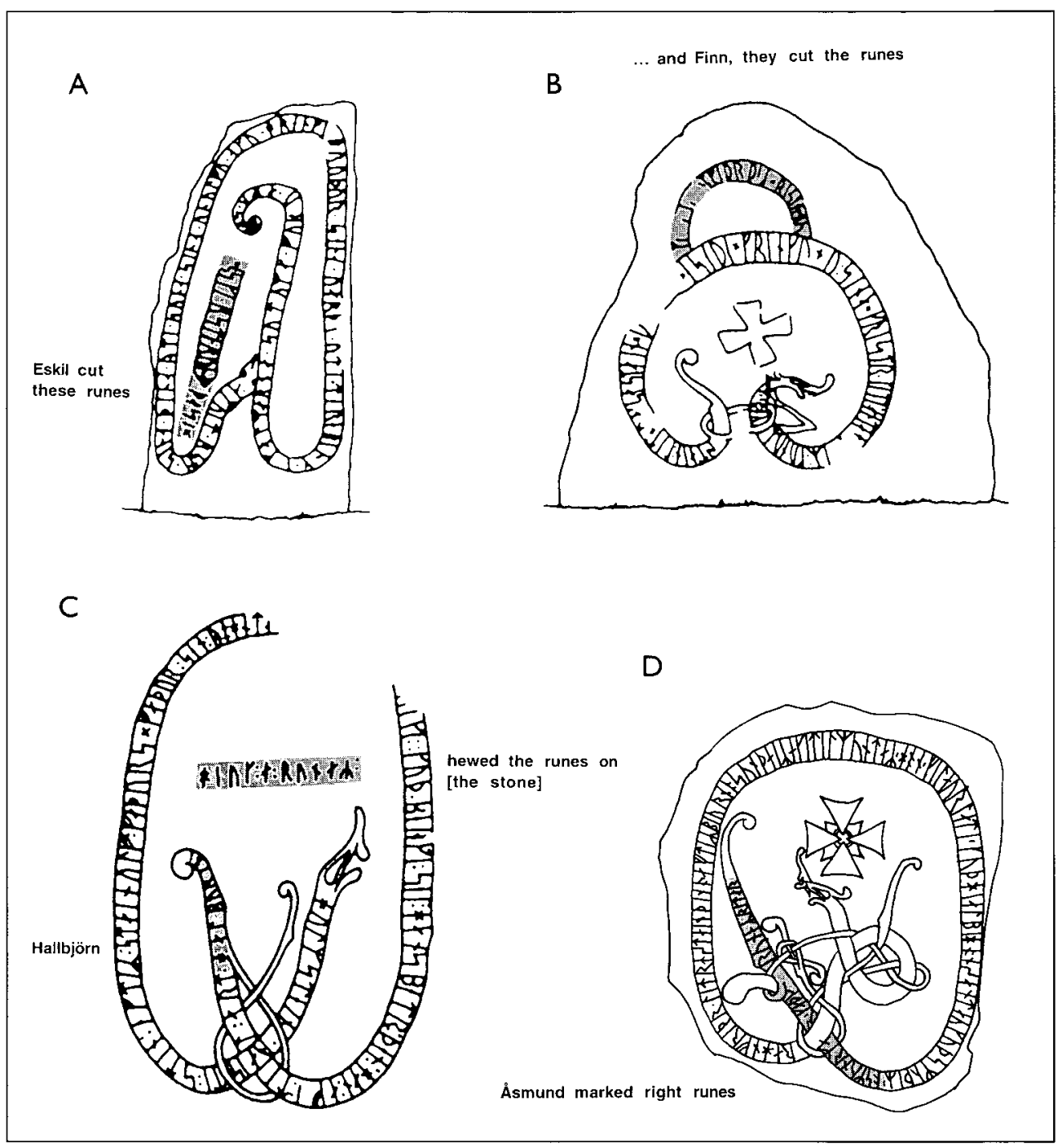

Fig. 6. Four rune-stones which illustrate the transition from textual additions to small snakes and tails of snakes without texts. All the examples are related to rune carvers.

A (Ärja, Sö 333). Main snake: "Amunde raised this stone after his son Runulv and after Ring, his brother: [He] was killed out on Kalmarsund, [when they] went to Skåne"

Extra text-band: "Eskil cut these runes"

$B$ (Korpabro, Sö 139). Main snake: "Sten had this stone raised after Äshed, his relative. Christ give relief for her soul, a good woman"

Extra text-band: "... and Finn, they cut the runes"

C (Brösicke, Sö 195). Main snake: "Holmsten raised the stone after Stenulv, his grandfather, a good yeoman who lived in Brösicke. Gud help his soul better than he deserved. Hallbjörn"

Extra runes: "hewed the runes on [the stone]"

$D$ (Frösunda, U 346). "Ragnfrid had this stone raised after Björn, her and Kättilmund's son. He was killed in Virland. God and God's mother help his soul. Åsmund marked right runes" 


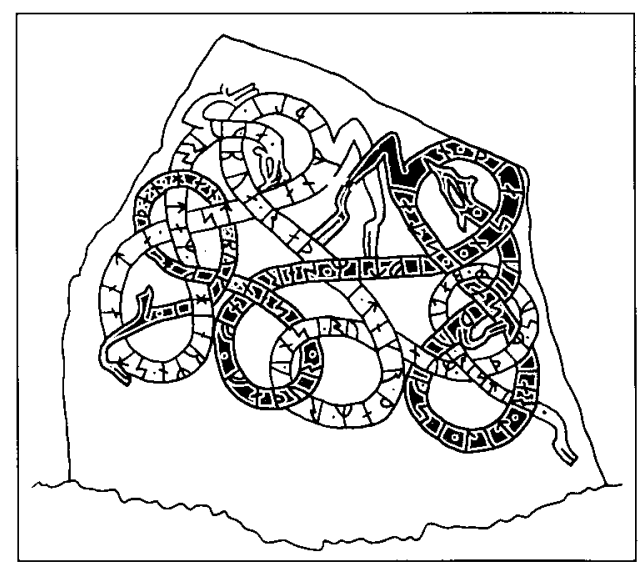

Fig. 7. Rune-stone at Agersta in southern Uppland (U 729). The monument is an example of how complex word crossings can extend the meaning of the text. In the following translation words from the opposite snake are marked in parentheses.

Right snake (shaded): "Vidhugse had this stone raised (those runes that Balle carved) in memory of Särev, his good father (who rune-wise is). He lived at (Ågersta)"

Left snake: "(He lived at) Agersta. Here shall stand the stone between farms. Let that man solve who rune-wise is (his good father) those runes that Balle carved (Vidhugse had this stone raised)".

each other. The close relationship between the text and the plaited snakes is especially clear in the above-mentioned inscription at Hillersjö (fig. 3). The rune-carver Torbjörn Skald had usually employed points to make divisions between words. In 16 cases, however, he had instead used crossing parts of a snake as worddivider. In this case, the design of the inscription can be regarded as extremely "well planned" (cf. Meijer 1992).

The rune-carvers did not only use plaited snakes as division between words, but also as means to create visual associations between words that were not textually related. A good illustration of this visual association is the rune-stone at Ågersta (fig. 7) in southwestern Uppland. The rune-carver Balle created three different clusters of word crossing through the intertwined snakes. In the right part of the inscription is a cluster of word crossing that emphasises the relationship between the rune-carver and the man who had the stone raised. A cluster in the left part of the inscription underlines the location of the stone and its relation to the farm where the dead man had lived. Finally, a centrally placed cluster of word crossing holds up the character of the dead man, especially his knowledge of runes. This aspect of the dead man's character, however, is not evident from the inscription as a linear text.

The word crossing gives an associative understanding of the text, which closely resembles skaldic poetry. Just as poetry was bound together by grammar and metric elements such as alliteration, the runic inscriptions were tied together by intertwined snakes with texts.

The combined composition of the text and the plaited snakes is in several cases highly sophisticated, and therefore it is very interesting that the rune-carver at Hillersjö in fact called himself skald (poet).

\section{Images}

Many rune-stones contain images or standardised symbols like a cross in connection with the texts. In a few cases, as with the large rune-stone at Jelling in Denmark (DR 42), image and text have been interpreted together (Fuglesang 1986; cf. Moltke 1974). Usually, though, the images have been interpreted in isolation, without references to the rest of the rune-stones. From my point of view, these images should be regarded as part of the total composition, and consequently they are very important for the re-reading of the rune-stones. The close connection between image and text can be illustrated by two examples.

One rune-stone at Tumbo in western Södermanland (fig. 8) is dominated by a large beast with sharp teeth. According to the inscription, the stone was raised for a certain Frösten who "was dead" in Greece. The word "dead" (PuPR) was cut directly in front of 


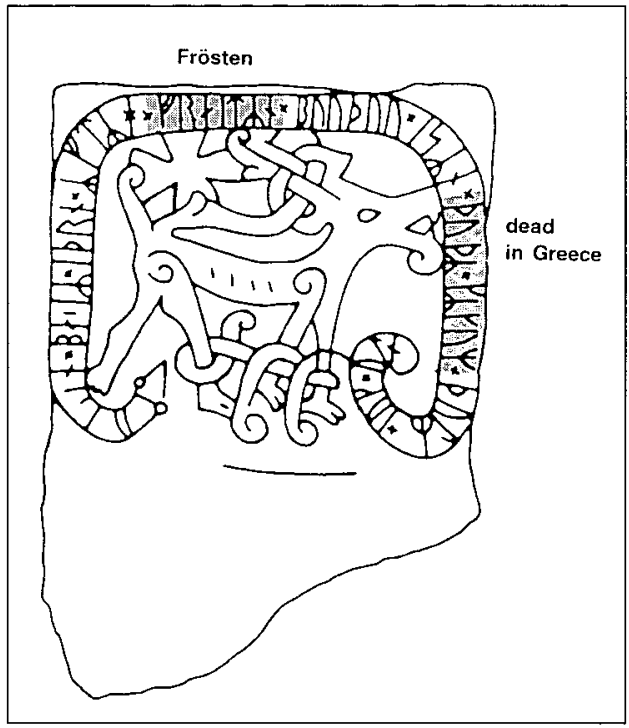

Fig. 8. Rune-stone at Tumbo (Sö 82). The stone is an example of the close relationship between text and image. The inscription runs: "Visten raised the stone after Frösten, his brother; dead in Greece. Tule hewed runes".

the jaws of the beast. This relation between image and text can be interpreted with reference to Norse mythology. According to several poems the metaphor for being killed in a battle was that the wolf was fed (for instance Sämunds Edda pp. 127, 193; and Snorres Edda p. 173). The beast at Tumbo can consequently be interpreted as a wolf, and the close relation between the wolf's jaws and the word "dead" implied for the well-informed reader that Frösten had died in a battle, although that was not directly mentioned in the text.

Another example is the well-known runecarving at Ramsundsberget in north-western Södermanland (fig. 9), with illustrations of the hero Sigurd in the Volsunga saga. According to the text the carving had been made by Sigrid for her dead husband. Two men are named, Holmger and Sigröd, but the text is a bit obscure, which means that it is difficult to determine the name of her husband (cf. Jesch 1991b). From an iconographic point of view I would argue that Sigröd was her dead husband's name, since Sigröd is the local form of Sigurd. It is only this interpretation that gives a comprehensible solution of the adjacent images. The widow Sigrid had used the pagan virtues of the Volsunga saga to commemorate her dead husband Sigröd. The images implied that he had been as heroic as his namesake the famous hero Sigurd

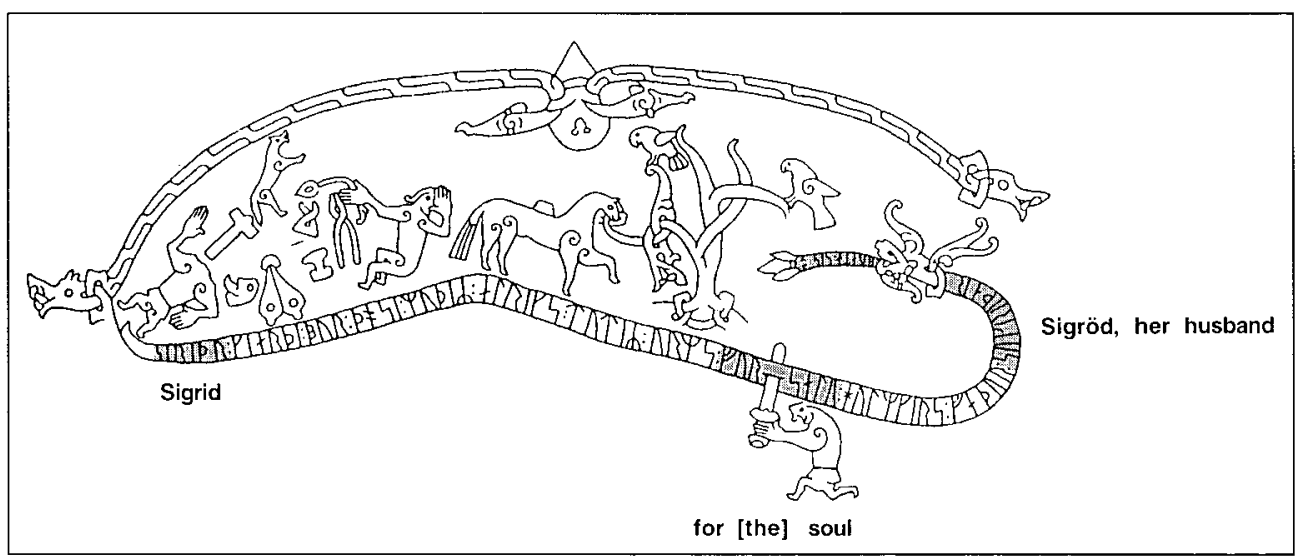

Fig. 9. Runic inscription at Ramsundsberget (Sö 101). This famous monument with illustrations of the Volsunga saga is another example of the close relationship between text and image. On the basis of the images the partly obscure inscription can be interpreted as follows:

"Sigrid, Alrik's mother, Orm's daughter made this bridge for [the] soul of Holmger's father Sigröd, her husband". 


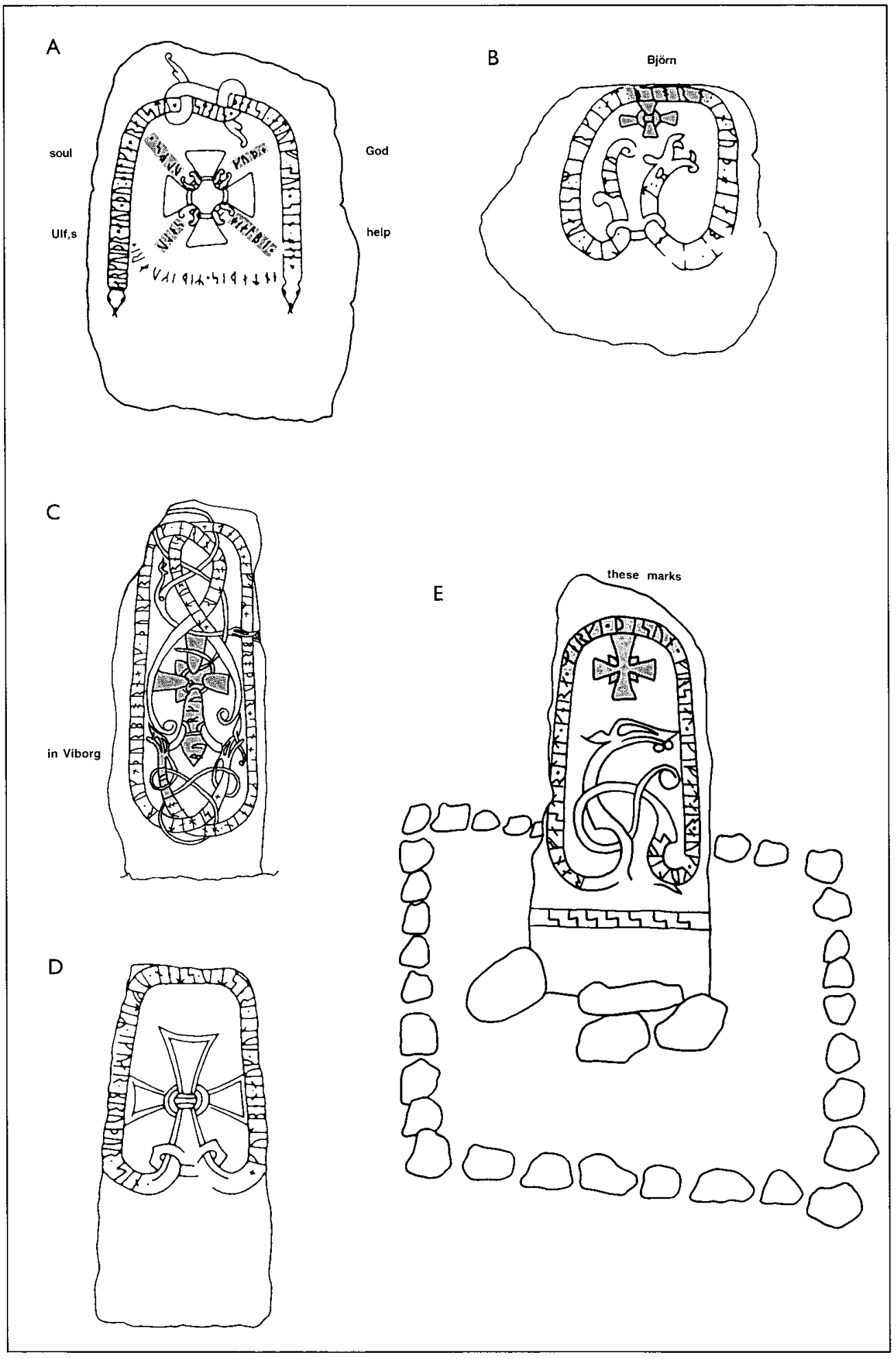


Fig. 10. Five rune-stones illustrating how the cross could be combined with different aspects of the text.

A. Cross and Christian prayer (Lifsinge, Sö 9). Main snakes: "Bergvid, he and Helga raised this stone after Ulf, their son. He"

Text between snakes: "passed away with Ingvar"

Text around the cross: "God help Ulf's soul"

B. Cross and personal name (Ostra, Sö 118): "Öind had the memorial raised after Björn and God help the soul"

C. Cross and place-name (Össeby-Garn, U 180). Left snake: "Sigvat and Torbjörn and Torgrim and Ärenmund" Right snake: "had the stone raised after their brother Sigsten. He died in Vi-" Cross: "borg"

D. Cross and the main loop (Tumbo, Sö 362): "Kolben and Jule raised the stone after Ingvar, their brother"

E. Cross and the concept of the monument (Tibble, U 496): Ragnfast had these marks done for the souls of Ingefast and Gullev".

Fafnisbani. However, the carving has at the same time clear Christian allusions. According to the text the widow had a bridge made "for the soul ... of her husband". The words "for the soul" (fur salu) were cut exactly where the hero Sigurd stabbed his sword into the body of the dragon Fafnir. This close connection between image and text indicates that the whole composition of the carving expressed a dilemma for those persons who experienced Christianisation. According to pagan virtues a man should be heroic and kill people in battle, but according to Christian ethics he should in principle not kill another person. The crossing of the sword and the words "for the soul", which in itself forms a cross, can therefore be regarded as a kind of prayer for the dead husband who had killed during his life.

This kind of close connection between image and text can also be found in more recurring images such as crosses and large animals. Crosses on rune-stones have in several investigations been studied in relation to form, chronology and provenance (Wideen 1955; Thompson 1975; Lindblad \& Wirtén 1992; Lager 1995), but not in relation to more specific meanings based on the appearance of the crosses on the rune-stones. However, a comparison of the placing of the crosses and the texts on the rune-stones clearly shows that the crosses had different signification according to the spatial context. Some crosses are placed in the middle of the stone, without direct relation to the text (fig. 10A). The meaning of this location is directly expressed on a rune-stone at Lifsinge in eastern Södermanland (Sö 9), where the prayer "God help Ulf's soul" is written around the cross. A similar connection between cross and prayer is indicated by two rune-stones from the parish of Ytterselö in northern Södermanland (Sö 197 and 203). The inscriptions on these rune-stones are identical, apart from a Christian prayer ending one of the stones. On the other stone this prayer is replaced by a cross. In these examples the cross stands for a prayer directed towards God.

In other instances the cross has been cut directly by the name of the dead person who is commemorated, for instance "Björn" and "Frösten" (fig. 10B, cf. fig. 8). This context rather indicates a "dead Christian", in other words that the dead person had had a Christian funeral. In some cases the person had died abroad, and consequently the cross can be regarded as a reassurance that the person received proper Christian treatment when he or she was buried far from home. The location of the death and the funeral was in other words important, and sometimes this location was emphasised by a close connection between the cross and a place name. On the rune-stone at Össeby-Garn in southern Upp- 
land (U 180) the sentence "He died in Viborg" is partly written in the cross itself (fig. 10C).

On some rune-stones the cross is part of the ribbons with text (fig. 10D; cf. Lindblad \& Wirtén 1992). Since I have interpreted the main text-bands as signifying families, this location of the cross may instead indicate that the family as a whole was Christian, perhaps after a Christian wedding. Finally, some crosses have been cut in direct relation to words signifying the monument itself, like "this stone" (cf. Sö 97) or "these marks". In these instances the cross seems to signify that the monument in itself was Christian. One example comes from the grave-field at Tibble in southern Uppland (U 496), which has been discussed by Anne-Sofie Gräslund (fig. 10E). According to her this rune-stone was connected to a Christian grave, and marked out that the grave-field became Christian (Gräslund 1988). This context may explain why it was important to underline that the monument in itself was Christian.

Another common image was a large animal, placed adjacent to the snakes. It is known from several rune-stones in central Sweden, and the recurring pattern is that the animal appears on stones where a man is commemorated as "good" or "best" (cf. fig. 2). "Good" was a central concept of honour (Herschend 1998a), and consequently the animal should in some way be related to that concept. The animal is well-known in late Viking Age art, not only from rune-stones but also from brooches, caskets and weathercocks. It has in other contexts been interpreted as a Scandinavian form of the lion as a symbol of lordship (Fuglesang 1986; cf. Hyenstrand 1996:153 ff.). This interpretation fits well with a relation between the animal/ lion and the concept "good". To be "good" was to behave correctly towards friends, servants or a household, i.e. to execute lordship.

Thus, pictures on the rune-stones were not merely plain illustrations, but images composed in direct relation to the snakes and the texts cut into the snakes. Instead, the images functioned as allusions or associations, which underlined and extended the meaning of the texts.

\section{Back to the beginning}

Although space does not allow any further arguments here, I hope that the examples have shown that partly new meanings can be added to many rune-stones by a combined re-reading. Let me just turn back to my first example, the rune-stone at Nybble on Selaö (fig. 2). The iconography indicates very complex relations between the persons mentioned on the stone. The rune-carver placed himself at the beginning of the text in the head of a snake, probably because he was related to the dead man's widow, and maybe because he was the head of her family. However, he also used a small snake to mark out himself as a rune-carver, possibly in relation to the dead man's son. Finally, the rune-carver indicated by a word crossing that he could read and solve the meaning of the monument. The dead man was commemorated by the widow and a son, but since they are mentioned on two different snakes, the son probably belonged to another marriage. Finally, the fourlegged animal visually underlined that the dead man was "the best of dwellers" at Kil. Thus, a combined reading of the embodied texts and the image may lead to an interpretation that underlines and partly extends the semantic meaning of the text in itself.

\section{IMPLICATIONS OF A RE-READING}

My proposed re-reading of rune-stones from the $11^{\text {th }}$ century has several implications for the interpretation of these monuments that I want to comment on, in this concluding section. The proposed re-reading must first of all be regarded as an attempt to extend current interpretations of the rune-stones. I have no intention to disprove the philological interpretations in Sveriges runinskrifter, rather the contrary. The aim is instead to complement these interpretations with a more 
associative close reading, by interpreting the ornamental loops and images together with the texts. This re-reading can affect the interpretation of most rune-stones from the $11^{\text {th }}$ century, but not all of them, since some consist only of texts or ribbons with text.

\section{Tendencies and exceptions}

I have deliberately used a qualitative method when presenting the different elements of understanding, in contrast to many recent quantitative studies of the rune-stones and their inscriptions (for instance Sawyer 1988; Herschend 1994; Johansson 1996). The character of the re-reading excludes quantitative methods, at least initially. The problem of using quantitative methods can be illustrated by the animal which bears many of the runic inscriptions. If we want to make a classification of this creature it is not possible to use quantitative methods, since the animal is named only once, as "snake" (ormaluR) on a rune-stone at Hogrän on Gotland (Go 203). Thus, the classification of the animal must be argued from this sole good example and from the form of the creature, in combination with references in Norse literature (cf. Johansen 1997). My arguments for the significance of different elements on the rune-stones are in similar ways based on good examples.

Eventually, though, my re-reading must be confronted with a more quantitative approach. It is important, however, first to determine the basis for any statistical analysis (cf. Jesch 1994). In this article I have not used any statistics, but only referred to general tendencies which seem to support the rereading. There are exceptions to these tendencies, but they do not necessarily speak against my interpretations. Instead, my proposed associative interpretation may indicate other alternative meanings, as in the following example.

According to my interpretations, there is an obvious divergence between snake and text in the well-known rune-stones raised by Jarlabanke in southern Uppland (Gustavson
\& Selinge 1988). He had seven stones raised to himself, while he was still alive, and although he only mentioned himself they are all composed of two snakes. This difference between image and text can in this case be explained by the extraordinary context. Few other persons raised stones to themselves and no one raised as many as Jarlabanke. These extraordinary actions by Jarlabanke can be regarded as nearly desperate ways for him to claim property and other rights. By composing the stones with two snakes he alluded that these rights came from another family, most plausibly as an inheritance from his wife.

\section{Family forms}

Rune-stones, especially in central Sweden, have in recent years been used in studies concerning gender, families, inheritance, and property. The re-reading of the rune-stones may partly have consequences for these studies, and I will comment on one category of cases. Most stones with two snakes can be explained by complex family ties mentioned in the texts. In some instances, especially in Uppland, there is no such correlation between image and text. Although the stones are composed of two snakes, only two or more persons are mentioned as sponsors, usually two or more children. If we want to maintain that snakes generally speaking represented different families, the only possible solution of these compositions is that the sponsors were half-brothers and half-sisters, although that was not mentioned in the texts.

To further explain why there were so many half-brothers and half-sisters may open up for a new social perspective on families in $11^{\text {th }}$ century central Sweden. A plausible explanation is that polygamy was common, creating very complex family ties, which were expressed through the iconography of the rune-stones. There are at least two direct instances of polygamy in Södermanland and Uppland, although the editors of Sveriges runinskrifter have tried to explain away these 


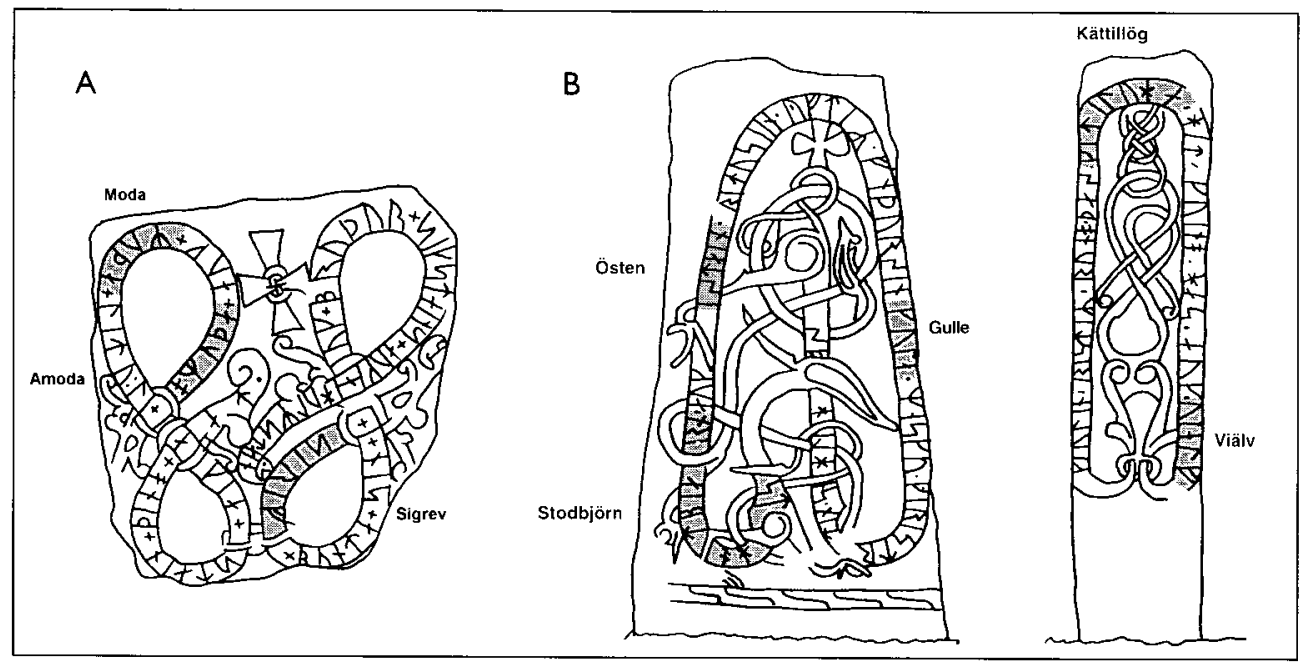

11. Two rune-stones with information of possible polygamy.

A (Uppinge, Sö 297). Left snake: "Amoda and Moda had this stone laid after" Right snake: "Sigrev, their husband and Sigsten's and Holmsten's brother"

$B$ (Bräcksta, U 1039). Left side: "Stodbjörn and Östen raised the stone in memory of their father Gulle. Mercy has Christ, give relief to his soul"

Right side: "Kjule (?) carved these runes. Kättillög was his wife called, and Viälv".

cases (fig. 11). At Uppinge in eastern Södermanland (Sö 297) two women raised a runestone in commemoration of "their husband" and at Bräcksta in northern Uppland (U 1039) two women are mentioned as the dead man's wives. In both instances the stones are composed of two snakes with texts. The idea of common polygamy can be further supported by the writings of Adam of Bremen in the $1070 \mathrm{~s}$. According to him many powerful and rich men among the Svear had several wives, and all the children in these polygamous families had equal rights of inheritance (Adam 1984:219). Adam, in other words, seems to describe a kind of official polygamy among the Svear, which was partly different from the usual Scandinavian custom of concubines among powerful men.

The proposed re-reading of the runestones has accordingly led to a reconsideration of a seldom-noticed aspect of family forms in central Sweden (cf. Larsson 1996). This family form may, however, explain why rune-stones were often commissioned by many persons in central Sweden, in contrast to southern Scandinavia, where a sole sponsor was much more common (cf. Saywer 1988). The family forms have to be further investigated, but if polygamous families really were common, this kinship pattern will have large implications for the archaeological analysis of graves and grave-fields (cf. Petré 1984, 1993).

\section{Sponsors and carvers}

Another field of research has been the role and function of the rune-carvers. Especially the question why the carvers did or did not sign the rune-stones has been discussed in recent years (Thompson 1975; Åhlén 1997; Herschend 1998b; Stille 1999). The proposed re-reading may also illuminate this debate. Most runic inscriptions from the $11^{\text {th }}$ century including the rune-carver were composed with extra small snakes twisted around the name of the rune-carver (cf. figs. 2 and 5). As mentioned above, this composition indicates a hierarchical relation between sponsor 
and rune-carver. The question is why this relation in some cases has been important to emphasise, for sponsors as well as carvers.

My interpretation is that the composition shows a personal agreement of service between the sponsor (large snake with text) and the rune-carver (small twisted snake without text). Sometimes several small snakes are intertwined around the large snake, which consequently may indicate that several craftsmen were employed to execute the stone, although only one rune-carver is mentioned. An example of this situation is known from the runestone at Hogrän on Gotland (Go 203), which was executed by three men, one who drew the snake and two who cut the runes.

It may have been important to express this kind of formal service for both sides. The sponsor or sponsors could show their ability and power, by mentioning men in their service on the stone. For the carvers, as for any "free man", it was honourable to be in the service of powerful men (cf. Ólason 1989), and therefore it must have been important to sign the stones. From this perspective the unsigned rune-stones must have been executed in other social circumstances. They were not the result of a personal service, but instead the rune-carver must have executed the unsigned rune-stones as non-personal commissions, for instance by selling the unsigned stones to the sponsor.

The difference between the signed and the unsigned stones may thus have some important social implications. The signed stones show where rune-carvers, alone or with assistants, were part of prosperous households for a period of time, whereas unsigned stones show households only commissioning a monument and not having craftsmen in their service. If the attribution of unsigned runestones to known rune-carvers is correct, it means that the craftsmen could manufacture rune-stones in different social contexts during the $11^{\text {th }}$ century.

\section{Cut and spoken expressions}

The close composition of texts, images and ornaments is mainly an innovation of the $11^{\text {th }}$ century, and more detailed study of this innovation would, therefore, be of interest. In this context, however, I will just make a few remarks concerning the style of the runestones and its development. The large wave of erecting rune-stones in the late Viking Age started in Denmark in the second part of the $10^{\text {th }}$ century. More or less as a starting point for this wave stands the large rune-stone at Jelling (DR 42). The text on this monument was not cut on snakes, but on horizontal ribbons, in a much more textual manner than the later rune-stones from the $11^{\text {th }}$ century. Already on this stone, however, there is a close spatial connection between text and image. Contemporary Christian manuscripts have been pointed out as models for the complex design of this monument (DR 42; Fuglesang 1986; Wamers 1999).

The introduction of snakes as bearer of texts, however, occurred later, probably a few decades after the erection of the large runestone at Jelling. Early examples with very simple snakes, from about the year 1000, are the rune-stones at Sporup in northern Jutland (Moltke 1976:212 pp.), at Torna Hällestad in Skåne (DR 296) and at Aspa Löt in southern Södermanland (Snæsdal Brink \& Wachtmeister 1984:129). Later on, these snakes were designed in contemporary styles of animal art, especially on Gotland and in central Sweden. Since nearly all late Viking Age rune-stones are Christian, the transition from Christian manuscript to animal art can be explained by strategies connected with the Christianisation of Scandinavia. As pointed out by several scholars, the Christian message had to be adjusted and even translated to Norse expressions to be understood at all, during the conversion (Danbolt 1989; Russell 1994; Zachrisson 1998:135 ff.). The use of animal art on the rune-stones may accordingly be regarded as one of several examples of such a Christian adjustment and strategy. 
Only when the Christian church was more firmly organised in the $12^{\text {th }}$ century did animal art as well as rune-stones disappear, and instead the international Romanesque style was introduced as a proper expression of the Christian message (Andrén 1999; cf. Zachrisson 1998:135 ff.).

The incorporation of texts into animal art in the $11^{\text {th }}$ century may also shed light on the recent debate concerning animal art in general. The proposed re-reading clearly shows that animal art was meaningful, but only in a restricted sense. Animal art should above all be regarded as a special kind of expression, used to convey different messages. In this respect, animal art was analogous to skaldic poetry, as several scholars have pointed out. Both genres were difficult forms of expression, which demanded special craftsmen to be created and good background knowledge to be understood. In fact a few rune-carvers called themselves skald (poet).

Animal art was a dominant form of artistic expression in Scandinavia from the $5^{\text {th }}$ century until the $12^{\text {th }}$ century. More than 100 different styles in animal art have been defined in the $20^{\text {th }}$ century and these definitions have sometimes been regarded as only modern classifications, with little relevance for past "realities" (cf. Karlsson 1983:92 ff.). The similarity between animal art and skaldic poetry instead speaks in favour of some kind of relevance for the different styles. They can be regarded as visual stanzas or visual metres by analogy with the metric forms of skaldic poetry that are described by Snorri in his Háttatal (Snorres Edda, pp. 219-265.) From this point of view different styles of animal art, like the Mammen style and the Urnes style, may be regarded as analogous to poetic metres like Dróttkvætt and Fornyrdislag (cf. Lie 1952; Bugge 1953). It is even possible that the different art styles had the same social connotation as some of the poetic metres.

\section{Levels of understanding}

The proposed associative close reading of rune-stones presupposes some kind of intellectual understanding of the monuments, and it is uncertain how common such an understanding might have been in the $11^{\text {th }}$ century. It is quite clear from Norse literature that some persons were "unwise", i.e. had not the knowledge to understand the metaphors and allusions in skaldic poetry. Therefore, the message that the rune-stones conveyed has probably been apprehended in several different ways, at least from an individual point of view. The rune-stones could be understood at a monumental point of view, as brightly coloured monuments, signifying important places and persons in the landscape. They could also be understood from an iconographic level, since the images and the number and size of snakes indicated different relations between persons. A literate person could further understand the runic inscription in a literal sense, by reading the text. And finally, a person well-informed in Norse mythology could understand the monument from a poetic point of view.

However, it is questionable whether the understanding of the rune-stones was individually based in that way. From the Poetic Edda as well as the Snorri's Edda it is clear that interpretations of mythological knowledge were enacted collectively, sometimes as competitive wisdom-dialogues between two persons (Holtsmark 1960). Thus, it is plausible that the understanding of the runestones should be apprehended as a kind of interpretative context, including several persons contributing to a joint interpretation, as a kind of collective act.

A final problem, though, is that such an understanding partly must have been based on the eye as the important active sense. It is only through vision that the sophisticated compositions of the rune-stones were accessible. However, this active use of the eye is difficult to combine with a dominant oral culture, where texts usually were accessible through listening. And most probably Scandinavia in the late Viking Age was a thor- 
oughly oral culture (cf. Goody 1977, 1986; Clanchy 1979; Ong 1982; Schousboe \& Trolle Larsen 1989; Lindell 1994). The solution to this problem can be to regard the rune-stones with their complex compositions as analogies to Arabic calligraphy on monuments (Blair 1989; Baer 1998). That type of public writing was not intended for silent reading, but created as contemplative texts, which needed long interactive interpretations, probably involving several persons. In that way, the rune-stones with their intricate compositions can be viewed as contemplative monuments, which demanded that the persons passing them had to stop and discuss their meaning. The sophisticated compositions accordingly underlined the very aim of the monuments, namely to be memorials. Thus, function and meaning of the runestones are clearly intertwined, and their design, text, image and location therefore should not be separated in future research.

\section{English revised by Alan Crozier:}

\section{ACKNOWLEDGEMENTS}

This paper has been presented at seminars in Malmö, Bergen, Stockholm, Uppsala and Lund during 1998-99. Comments and questions raised on these occasions have been very useful in writing the article. Moreover, I want to thank Stefan Brink, Sanne HoubyNielsen, Jörn Staecker and Jes Wienberg for comments on the manuscript.

\section{REFERENCES}

Åberg, N. 1921. Stil III och Jellingestil. Fornvännen. Pp. 63-82.

- 1922. Stil II. Fornvännen. Pp. 1-26.

Adam av Bremen. 1984. Historien om Hamburgstiftet och dess biskopar. Översatt av Emanuel Svenberg. Stockholm.

Åhlén, M. 1997. Runristaren Öpir: En monografi. Runrön 12. Uppsala.

Ambrosiani, B. 1964. Fornlämningar och bebyggelse. Studier i Attundalands och Södertörns förhistoria. Kungliga Vitterhets, Historie och Antikvitetsakademien, Monografier. Uppsala.

Andersson, H. 1995. Kristendomens genombrott - en studie av runstenarna i Upplands-Bro. Duplicated seminar paper. Institute of Archaeology, University of Uppsala. Uppsala.

Andersson, L. 1992. Rumstenar som uttryck för samhällsförändring. En studie av runstenar och samhälle under 1000-talet i Mälardalen. Duplicated seminar paper. Department of Archaeology, Stockholm University. Stockholm.

1989. Dörrar till förgångna myter. En tolkning av de gotländska bildstenarna. In: Andrén, A. (Ed). Medeltidens födelse. Symposier på Krapperups borg 1. Krapperup. Pp. 287-319. 1993. Doors to other worlds. Scandinavian death rituals in Gotlandic perspectives. Journal of European Archaeology 1. Pp. 33-56.
- 1998. Between Artifacts and Terts. Historical Archaeology in Global Perspective. Contributions to Global Historical Archaeology. New York.

- 1999. Landscape and settlement as utopian space. In: Fabech, C. \& Ringtved, J. (Eds). Settlement and Landscape. Århus. Pp. 383393.

Arend, Q. 1978. ybiR risti runaR. Zur Sprache eines uppländischen Runenmeisters. Amsterdamer Beiträge zur älteren Germanistik 13. Pp. 35-67.

Axelsson, J. 1993. Mellansvenska runistare. Förteckning över signerade och attribuerade inskrifter. Runrön 5. Uppsala.

Bæksted, A. 1952. Målruner og roldruner: Runemagiske studier. Nationalmuseets skrifter. Arkæologisk-Historisk Række IV. Copenhagen.

Baer, E. 1998. Islamic Ornament. Edinburgh.

Baines, J. 1989. Communication and display: the integration of early Egyptian art and writing. Antiquity 63. Pp. 471-482.

Bérard, C., Bron, C., Durand, J.-L., FrontisiDucraux, F., Lissarrague, F., Schnapp, A. \& Vernant, J.-P. 1989. A City of Images. Iconography and Society in Ancient Greece. Princeton.

Berg, S. 1987. Och Öpir ristade. En studie kring en uppländsk runristare. Duplicated seminar 
paper. Department of Archaeology, Stockholm University. Stockholm.

Bergman, B. 1948. Uppländsk run- och bildstensristning. En konsthistorisk studie. Stockholm.

Berlo, J. C. (Ed). 1983. Text and Image in PreColumbian Art. Essays on the Interrelationship of the Verbal and Visual Arts. British Archaeological Reports. International Series 180. Oxford.

Bjurström, A. 1996. Vem reste runstenarna? En studie av fem genealogiskt kopplade runstensgrupper $i$ Håbo och Arlinghundra härad. Duplicated seminar paper. Institute of Archaeology, University of Uppsala. Uppsala.

Blair, S. S. 1989. Legibility versus decoration in Islamic epigraphy. The case of interlacing. In: Laum., I. (Ed). World Art. Themes of Unity in Diversity. Acts of the Congress of the History of Art II. Pennsylvania. Pp. 329-334.

Brate, E. 1925. Svenska runristare. Kungliga Vitterhets, Historie och Antikvitets Akademiens Handlingar 33:5-6. Stockholm.

Brøndsted, J. 1920. Nordisk og fremmed Ornamentik i Vikingetiden, med særlig Henblik paa Stiludviklingen i England. Aarbøger for nordisk Oldkyndighed og Historie III:10 Pp. 162-282.

- 1924. Early English Ornament. The sources, development and relation to foreign styles of pre-roman ornamental art in England. London \& Copenhagen.

Bugge, A. 1953. Norske stavkirker. Oslo.

Carlqvist, K. 1977. Vad säger runstenarna? Meddelande frain arkivet för folkets historia 5:4. Pp 8-21.

Carlsson, M. 1985. Thegn - Dräng - Jarl Huskarl. Arkeologiska studier utifràn runstenar i östra Mellansverige. Duplicated seminar paper. Department of Archaeology, Stockholm University. Stockholm.

Christiansson, H. 1959. Sydskandinavisk stil. Studier $i$ ornamentiken på de senvikingatida runstenarna. Uppsala.

- 1995. Den onda ormen. Runstensornamentikens kristna budskap. Ett tolkningsförsök. TOR 27. Pp. 449-457.

Christophersen, A. 1982. Drengs, Thegns, Lendmen and Kings. Meddelanden frän Lunds Universitets Historiska museum, New series, Vol. 4. Pp. 121-134.

Claesson, E. 1982. Götalandskapens runstenar. Duplicated seminar paper. Institute of Archae- ology, University of Lund. Lund.

Clanchy, M. T. 1979. From Memory to Written Record. England 1066-1307. London.

Crocker, K. R. 1982. "Fotr risti". A Runographer's Style in the Context of EleventhCentury Upplandic Memorial Art. Ann Arbor.

Danbolt, G. 1989. Hva bildet kan fortelle om møtet mellom hedenskap og kristendom. In: Andrén, A. (Ed). Medeltidens födelse. Symposier på Krapperups borg 1. Krapperup. Pp. 233-260.

DR $=$ Danmarks runeindskrifter I-II. Ved Jacobsen, L. \& Moltke, E. under medvirkning af Bæksted, A. \& Nielsen, K. M. 1941-42. Copenhagen.

Ekblad, S. 1997. Den kristna missionen i Uppland speglad $i$ runstensmaterialet. Duplicated seminar paper. Institute of Archaeology, University of Uppsala. Uppsala.

Elgh, S. 1987. Runstenar-Placering och kristningsgrad. Danmark och Tiundaland - en jämförelse. Duplicated seminar paper. Institute of Archaeology, University of Uppsala. Uppsala.

von Friesen, O. 1913. Upplands runstenar. En allmänfattlig öfversikt. Uppsala.

- 1928. Runorna i Sverige. Uppsala.

- 1933. De svenska runinskrifterna. Nordisk kultur VI, Runorna. Stockholm.

Fuglesang, S. H. 1978. Stylistic Groups in Late Viking Age. In: Lang, J. T. (Ed). Anglo-Saxon and Viking Age Sculpture and its Context. British Archaeological Reports, British Series 49. Oxford. Pp. 205-223.

- 1980. Some Aspects of the Ringerike Style. A phase of $11^{\text {th }}$ century Scandinavian Art. Medieval Scandinavia, Supplements 1. Odense.

- 1981. Crucifixion Iconography in Viking Scandinavia. In: Bekker-Nielsen, H., Foote, P. \& Olsen, O. (Eds). Proceedings of the Eighth Viking Congress. Medieval Scandinavia, Supplements 2. Odense. Pp. 73-94.

- 1986. Ikonographie der skandinavischen Runensteine der jüngeren Wikingerzeit. In: Roth, H. (Ed). Zum Problem der Deutung frühmittelalterlicher Bildinhalte. Veröffentlichungen des Vorgeschichtlichen Seminars der Phillips Universitet, Marburg. Sigmaringen. Pp. 183-210.

Go $=$ Gotlands runinskrifter $\mathrm{I}-\mathrm{II}$, granskande och tolkade av Jansson, S. B. F., Wessén, E. \& 
Svärdström, E. Sveriges runinskrifter 11-12. Stockholm 1962-1978.

Goody, J. 1977. The Domestication of the Savage Mind. Cambridge.

- 1986. The Logic of Writing and the Organization of Society. Cambridge.

Gräslund, A.-S. 1985. Den tidiga missionen i arkeologisk belysning - problem och synpunkter. TOR 20. Pp. 291-314.

- 1988. Runstenar, bygd och gravar. TOR 21. Pp. 241-262.

- 1989. "Gud hjälpe nu väl hennes själ”. Om runstenskvinnorna, deras roll vid kristnandet och deras plats i familj och samhälle. TOR 22. Pp. 223-244.

- 1991. Runstenar - om ornamentik och datering TOR 23. Pp. 113-140.

- 1992. Runstenar - om ornamentik och datering II. TOR 24. Pp. 177-201.

- 1994. Rune Stones - On Ornamentation and Chronology. In: Ambrosiani, B. \& Clarke, H. (Eds). The Twelfth Viking Congress. Birka Studies 3. Stockholm. Pp. 117-131.

- 1996. Runstenskvinnorna ännu en gång. TOR 27. Pp. 459-474.

Grønvik, O. 1981. Runene på Tunesteinen. Oslo.

- 1985. Runene på Eggjasteinen. En hedensk gravinnskrift fra slutten av 600-talet. Oslo.

Gurevich, A. J. 1985. Categories of Medieval Culture. London.

Gustavson, H. \& Selinge, K.-G. 1988. Jarlabanke och hundaret. Ett arkeologiskt/runologiskt bidrag till lösningen av ett historiskt tolkningsproblem. Namn och bygd 76. Pp. 19-85.

Hagenfeldt, S. E. \& Palm, R. 1996. Sandstone Runestones. The use of sandstone for erected runestones. Runica et mediævalia 2. Stockholm.

Hallencreutz, C. F. 1982a. Runstenarnas Maria. En studie av kristendomens översättning till runsvenska. Svensk missionstidskrift 70:2. Pp 12-22.

- 1982b. Runstenarnas teologi. Signum 8:1. Pp. 9-15.

Hanks, W. F. \& Rice, D. S. (Eds). 1989. Word and Image in Maya Culture. Explorations in Language, Writing and Representation. Salt Lake City.

Haseloff, G. 1981. Die germanische Tierornamentik der Völkerwanderungszeit. Studien zu Salin's Stil I. Berlin \& New York.

Hedeager, L. 1997. Skygger af en anden virkelig- hed. Oldnordiske myter. Copenhagen.

- 1999. Skandinavisk dyreornamentik. Symbolsk repræsentation af en forkristen kosmologi. In: Fuglestvedt, I., Gansum, T. \& Opedal, A. (Eds). Et hus med mange rom. Vennebok til Bjorn Myhre på 60-årsdagen. Stavanger. Pp. 219-237.

Herschend, F. 1994. The Recasting of a Symbolic Value. Three Case Studies on Rune-stones. Occasional Papers in Archaeology 3. Uppsala.

- 1998a. The Idea of the Good in Late Iron Age Society. Occasional Papers in Archaeology 15. Uppsala.

- 1998b. ubiR, ybiR, ybir - är det U485 Ofeg Öpir? Fornvännen. Pp. 97-111.

Hildebrand, H. 1884. Det nya svenska runverket. Kongliga Vitterhets, Historie och Antiquitetsakademiens Månadsblad 13. Pp. 31-38.

Holmbäck, Å. \& Wessén, E. (Eds). 1943. Svenska Landskapslagar 4. Skånelagen och Gutalagen. Stockholm.

Holmqvist, W. 1951. Viking Art in the $11^{\text {th }}$ Century. Acta Archaeologica XXII. Pp. 1-56.

- 1955. Germanic Art during the First Millennium A.D. Vitterhetsakademien, Handlingar 90. Stockholm.

Holtsmark, A. 1960. Gudediktning. Kulturhistoriskt lexikon för nordisk medeltid 5. Malmö. Pp. 531-536.

Hübler, F. 1996. Schwedische Runendichtung der Wikingerzeit. Runrön 10. Uppsala.

Hyenstrand, §. 1974. Centralbygd-randbygd. Strukturella, ekonomiska och administrativa huvudlinjer $i$ mellansvensk yngre järnålder. Studies in North-European Archaeology 5. Stockholm.

- 1996. Lejonet, draken och korset. Sverige 5001000. Lund.

Jesch, J. 1991a. Women in the Viking Age. Woodbridge.

- 1991b. Who was hulmkir? Double apposition in the Ramsund inscription. Arkiv för nordisk filologi 106:125-136.

- 1994 Runic Inscriptions and Social History. Some Problems of Method. In: Knirk, J. E. (Ed). Proceedings of the Third International Symposium on Runes and Runic Inscriptions. Runrön 9. Uppsala. Pp. 149-162.

Johansen, B. 1997. Ormalur. Aspekter av tillvaro och landskap. Stockholm Studies in Archaeology 14. Stockholm.

Johansson, L. 1996. "Retta" och "rista". Tva 
runsvenska verb $i$ Mälardalen. Duplicated seminar paper. Institute of Archaeology, University of Uppsala. Uppsala.

Källström, M. 1992. Den uppländske runristaren Visäte. En kronologisk/korologisk studie. Duplicated seminar paper. Department of Archaeology, Stockholm University, Stockholm.

- 1998. Torbjörn skald och Torbjörn - studier kring två mellansvenska iunristare. Duplicated seminar paper. Institute of Scandinavian Languages, Stockholm University. Stockholm

Karlsson, L. 1983 Nordisk form - om djurornamentik. Statens historiska museum. Studies 3. Stockholm.

Klindt-Jensen, O. 1975. A History of Scandinavian Archaeology. London.

Kristoffersen, S. 1995. Transformation in Migration Period Animal Art. Norwegian Archaeological Review 28:1. Pp. 1-17.

Kyhlberg, K. 1983. Kvinnor och män i uppländska runinskrifter - en metodstudie. Duplicated seminar paper, Department of Archaeology, Stockholm University. Stockholm.

Lager, L. 1995. Kors på svenska runstenar. Duplicated seminar paper. Institute of Archaeology, University of Uppsala. Uppsala.

Lagerroth, U.-B., Lund, H., Luthersson, P. \& Mortensen, A. (Eds). 1993. I musernas tjänst. Studier $i$ konstarternas interrelationer. Stockholm \& Stehag.

Lagman, S. 1990. De stungna runorna. Användning och ljudvärde i runsvenska steninskrifter. Runrön 4. Uppsala.

Larsson, M. G. 1990. Runstenar och utlandsfärder: Aspekter av det senvikingatida samhället med utgångspunkt $i$ de fasta fornlämningarna. Acta Archaeologica Lundensia. Series in $8^{\circ}$, No. 18. Lund.

- 1996. Tvegifte i Täby? Några synpunkter på Jarlabankestenarnas datering och placering. Fornvännen. $\mathrm{Pp}$ 143-151.

- 1997. Från stormannagård till bondby. En studie av mellansvensk bebyggelseutveckling från äldre järnålder till medeltid. Acta Archaeologica Lundensia, Series in $8^{\circ}$, No 26. Lund.

Lie, H. 1952. Skaldestilstudier. Maal og Minne 1952. Pp.1-92.

- 1963. Kenningar. Kulturhistoriskt lexikon för nordisk medeltid 8. Pp 375-381. Malmö.
Lindblad, E. \& Wirtén, K. 1992. Korsbandsstenar - en kronologisk studie. Duplicated seminar paper. Institute of Archaeology, University of Uppsala. Uppsala.

Lindell, I. (Ed). 1994. Medeltida skrift-och språkkultur. Nio föreläsningar från ett symposium i Stockholm våren 1992. Runica et Mediævalia Opuscula 2. Stockholm.

Lindkvist, T. 1988. Plundring, skatter och den feodala statens framväxt. Organisatoriska tendenser $i$ Sverige under övergången fiån vikingatid till tidig medeltid. Opuscula Historica Upsaliensia 1. Uppsala.

Lindqvist, S. 1931. Yngre vikingastilar. Nordisk Kultur XXVII. Stockholm. Pp. 144-179.

Lindström, H. 1992. Senvikingatida runstenar $i$ Skandinavien. Kristna eller arvsrättsliga dokument? En jämförelse mellan Södermanland och Skåne. Duplicated seminar paper. Institute of Archaeology, University of Lund. Lund.

Ljungberg, H. 1938. Den nordiska religionen och kristendomen. Studier över det nordiska religionsskiftet under vikingatiden. Nordiska texter och undersökningar 11. Stockholm \& Copenhagen.

Lönnroth, E. 1982. Administration och samhälle i 1000-talets Sverige. Bebyggelsehistorisk tidskrift 4. Pp. 10-23.

Marcus, J. 1992. Mesoamerican Writing Systems. Propaganda, Myth, and History in Four Ancient Civilizations. Princeton.

Meijer, J. 1992. Planning in runic inscriptions. Blandade runstudier I. Runrön 6. Uppsala. Pp. 37-66.

Moltke, E. 1974. The Jelling monument in the light of the runic inscriptions. Mediaeval Scandinavia 7:183-208.

- 1976. Runerne i Danmark og deres oprindelse. Copenhagen.

Moström, J. 1998. Brostenar och själabroar: Organisation och ideologi bakom brobyggande i Norden under sen vikingatid och tidig medeltid. Duplicated seminar paper, Department of Archaeology, Stockholm University. Stockholm.

Müller, S. 1880. Dyreornamentiken i Norden. Aarboger for nordisk Oldkyndighed og Historie 1880. Pp. 185-405.

$\mathrm{NIyR}=$ Norges innskrifter med de yngre runer 15. Utgivne ved Olsen, M. Norges indskrifter indtil reformationen 2. Oslo 1941-1960. 
$\ddot{O} \mathrm{~g}=$ Östergötlands runinskrifter 1-3, granskade och tolkade av Brate, E. Sveriges runinskrifter 2. Stockholm 1911-1918.

Öl = Ölands runinskrifter 1-2, granskade och tolkade av Söderberg, S. \& Brate, E. Sveriges runinskrifter I. Stockholm 1900-1906.

Ólason, V. 1989. Den frie mannens selvforståelse $\mathrm{i}$ islandske sagaer og dikt. In: Andrén, A. (Ed). Medeltidens födelse. Symposier på Krapperups borg 1. Pp. 277-286.

Ong, W. 1982. Orality and Literacy. The Technologizing of the Word. London.

Ørsnes, M. 1966. Form og stil i Sydskandinaviens yngre germanske jernalder. Copenhagen.

- 1969. Südskandinavische Ornamentik in jüngeren germanischen Eisenzeit. Acta $\mathrm{Ar}$ chaeologica XL. Pp. 1-121.

Owe, J. 1995. Svensk runbibliografi 1880-1993. Runverket, Riksantikvarieämbetet. Stockholm.

Palm, R. 1992. Runor och regionalitet. Studier av variation i de nordiska minnesinskrifterna. Runrön 7. Uppsala.

Peterson, L. 1994. Svenskt runordsregister. Runrön 2. Uppsala.

Petré, B. 1984. Arkeologiska undersökningar på Lovö 4. Bebyggelsehistorisk analys. Acta Universitatis Stockholmiensis. Studies in North European Archaeology 10. Stockholm.

- 1993. Inheritance Systems and Farm Agglomerations Forming Early Villages in the Late Iron Age. In: Arwidsson, G. et al. (Eds). Sources and Resources. Studies in Honour of Birgit Arrhenius. PACT 38. Rixenart. Pp. 93106.

Philippa, M. 1977. Die Inschriften des schwedischen Runenmeister Balli. Amsterdamer Beiträge zur älteren Germanistik 12. Pp. 2345.

Ragnesten, U. 1978. Runstenar: En empirisk studie av sociala förhållanden $i$ runstenstexterna med en spatial jämförelse. Duplicated seminar paper. Institute of Archaeology. University of Gothenburg. Gothenburg.

Randsborg, K. 1980. The Viking Age in Denmark. The Formation of a State. London.

Russell, J. C. 1994. The Germanization of Early Medieval Christianity. A Sociohistorical Approach to Religious Transformation. Oxford.

Salberger, E. 1978. Runsvenska namnstudier. Stockholm Studies in Scandinavian Philology, New Series 13. Stockholm.
Salin, B. 1904. Die altgermanische Thierornamentik. Stockholm.

Sämunds Edda, översatt från isländskan av Brate, E. Stockholm 1913.

Sandahl, C. 1996. Kristendom, arv och utlandsfärder - en studie av småländska runstenar. Scripta Minora 31. Växjö.

Sawyer, B. 1988. Property and Inheritance in Viking Scandinavia. The Runic Evidence. Occasional Papers on Medieval Topics 2. Alingsås.

- 1989. Det vikingatida runstensresandet i Skandinavien. Scandia 55:2. Pp. 185-202.

- 1991. Viking-Age Rune-Stones as a Crisis Symptom. Norwegian Archaeological Review 24:2. Pp 97-112.

Sawyer, B. \& Sawyer, P. 1993. Medieval Scandinavia. From Conversion to Reformation circa 800-1500. Minneapolis \& London.

Schousboe, K. \& Trolle Larsen, M. (Eds). 1989. Literacy and Society. Copenhagen.

Schück, H. 1935-1944. Kungliga Vitterhets, Historie och Antikvitets Akademien I-VIII. Stockholm.

Segelberg, E. 1983. Missionshistoriska aspekter på runinskrifterna. Kyrkohistorisk årsskrift 83 . Pp. 45-57.

Shetelig, H. 1909. Urnesgruppen. Det siste avsnit av vikingetidens stilutvikling. Aarsberetning fra Foreningen til norske Fortidsmindesmerkers Bevaring.

- 1949. Classical Impulses in Scandinavian Art from the Migration Period to the Viking Age. Instituttet for sammenlignende kulturforskning. Serie A:XIX. Oslo.

Sjöberg, A. 1985. Orthodoxe Mission in Schweden im 11. Jahrhundert? In: Lindquist, S.-O. (Ed). Society and trade in the Baltic during the Viking Age. Acta Visbyensia VII. Visby. Pp. 69-78.

Snædal Brink, T. \& Wachtmeister, I. 1984. Runstenar $i$ Södermanland. Vägvisare till runristningar $i$ Södermanlands län. Sörmländska handlingar 40. Nyköping.

Snorres Edda. Översättning från isländskan och inledning av K. G. Johansson och M. Malm. Stockholm 1997.

Sö = Södermanlands runinskrifter 1-4, granskade och tolkade av Brate, E. \& Wessén, E. Sveriges runinskrifter 3. Stockholm 1924-1936.

Söderberg, S. 1905. Om djurornamentiken under folkvandringstiden. Antiquarisk tidskrift för 
Sverige XI:3. Pp. 1-93.

Söderqvist, E. 1993. Guds moder, ande och själ. Östligt inflytande $i$ Mälardalens runstensbönder. Duplicated seminar paper. Institute of Archaeology, University of Uppsala. Uppsala.

Stille, P. 1999. Runstenar och runristare $i$ det vikingatida Fjädrundaland. Runrön 13. Uppsala.

Strid, J.-P. 1987. Runic Thegns and Drengs. In: Runor och runinskrifter. Föredrag vid Riksantikvarieämbetets och Vitterhetsakademiens symposium 8-11 september 1985. Kungliga Vitterhets, Historie och Antikvitets Akademien, Konferenser nr 15. Stockholm. Pp. 301316.

Sundqvist, M. 1996. Treöglerunstenar i Uppland. Duplicated seminar paper. Institute of Archaeology, University of Uppsala. Uppsala.

Svärdström, E. 1936. Johannes Bureus' arbeten om svenska runinskrifter. Stockholm.

Svenbro, J. 1993. Phrasikleia. An anthropology of reading in ancient Greece. Ithaca, N.Y.

Thompson, C. W. 1975. Studies in Upplandic Runography. Austin \& London.

Thráinsson, Th. 1994. Vid Urdarbrunnen. Om Urnesstilens ikonografi. Duplicated seminar paper. Institute of Archaeology, University of Uppsala. Uppsala.

$\mathrm{U}=$ Upplands runinskrifter $1-4$, granskade och tolkade av Wessén, E. \& Jansson, S. B. F. Sveriges runinskrifter 6-9. Stockholm 19401958.

Varenius, B. 1998. "han ägde bo och skeppslid". Om rumslighet och relationer $i$ vikingatid och medeltid. Studia Archaeologica Universitatis Umensis 10. Umeå.

Wamers, E. 1999. Harald Blåtands dåb og den store Jellingsten. Vejle amts årbog 1999:4766.

Wideen, H. 1955. Västsvenska vikingatidsstudier: Arkeologiska källor till Vänerområdets kulturhistoria under yngre järnålder och äldsta medeltid. Skrifter utgivna av Göteborgs arkeologiska museum 2. Göteborg.

Wijkander, K. 1983. Kungshögar och socken- bildning. Studier i Södermanlands administrativa indelning under vikingatid och tidig medeltid. Sörmländska handlingar 39. Nyköping.

Williams, H. 1990. Asrunan. Användning och ljudvärde i runsvenska steninskrifter. Runrön 3. Uppsala.

- 1993. Möres runinskrifter. In: Williams, H. (Ed). Möres kristnande. Projektet Sveriges kristnande. Publikationer 2. Uppsala. Pp. 85116.

- 1996a. Vad säger runstenarna om Sveriges kristnande? In: Nilsson, B. (Ed). Kristnandet $i$ Sverige. Gamla källor och nya perspektiv. Projektet Sveriges kristnande. Publikationer 5. Uppsala. Pp. 45-83.

- 1996b. Runstenstexternas teologi. In: Nilsson, B. (Ed). Kristnandet i Sverige. Gamla källor och nya perspektiv. Projektet Sveriges kristnande. Publikationer 5. Uppsala. Pp. 291-312.

Wilson, D. M. 1995. Vikingatidens konst. Signums svenska konsthistoria 2 . Lund.

Wilson, L. 1994. Runstenar och kyrkor. En studie med utgångspunkt från runstenar som påträffats $i$ kyrkomiljö $i$ Uppland och Södermanland. Occasional Papers in Archaeology 8. Uppsala.

Zachrisson, T. 1994. The Odal and Its Manifestation in the Landscape. Current Swedish Archaeology 2. Pp. 219-238.

- 1998. Gård, gräns, gravfält. Sammanhang kring ädelmetalldepåer och runstenar frän vikingatid och tidigmedeltid i Uppland och Gästrikland. Stockholm Studies in Archaeology 15. Stockholm.

Zanker, P. 1988. The power of images in the age of Augustus. Ann Arbor.

\section{Sources of illustrations}

Figure 1 is a reproduction of an etching in Sveriges Runinskrifter, whereas figures 2, 3, 4, 5D, 6D, 7, $10 \mathrm{C}, 10 \mathrm{E}$, and 11 are drawings based on antiquarian images and photos published in Sveriges Runinskrifter. All other figures are based on figures in Snæsdal Brink \& Wachtmeister 1984. 